Jurnal Kesehatan Hesti Wira Sakti vol 9 No 12021

ISSN 2302-4283 (print)

ISSN 2580-9571 (online)

Online di https://jurnal.poltekkes-soepraoen.ac.id

DOI: $10.47794 /$

\title{
PENGARUH LOCUS OF CONTROL DAN DUKUNGAN SEBAYA TERHADAP RESIKO DEPRESI PADA ORANG DENGAN HIV DI KDS FRIENDSHIP PLUS KOTA KEDIRI
}

\author{
Endah Susanti $^{1}$, Erike Yunicha Viridula ${ }^{2}$, Astri Yunita ${ }^{3}$ \\ ${ }^{1}$ STIKes Bhakti Mulia Kediri, ${ }^{2}$ Universitas Kadiri \\ (Korespondensi: enzu.bd84@gmail.com )
}

\begin{abstract}
ABSTRAK
Kejadian HIV cenderung semakin meningkat dengan angka kematian yang tinggi, epideminya saat ini telah melanda seluruh negara serta semua lapisan penduduk, masalah sosial akan lebih memperberat kondisi psikis ODHA dalam stress dan depresi. Tujuan penelitian ini adalah menganalisis pengaruh locus of control dan dukungan sebaya terhadap resiko depresi di KDS Friendship plus Kota Kediri. Jenis penelitian ini adalah analitik observasional dengan pendekatan cross sectional. Penelitian ini dilaksanakan pada tanggal 23 - 24 April 2020. Pengambilan sampel dilakukan dengan teknik simpel random sampling sebanyak 45 subjek penelitian. Teknik pengumpulan data menggunakan kuisioner, analisis mengunakan regresi linier berganda. Pengaruh locus of control $\mathrm{p}=0.001$ (29.8\%). Pengaruh dukungan sebaya $\mathrm{p}=0.001$ (52\%). Pengaruh locus of control dan dukungan sebaya $(\mathrm{p}=0.001<0.005), 54 \%$ resiko depresi pada ODHA di pengaruhi oleh faktor locus of control dan dukungan sebaya, nilai koefisien regresi (b) locus of control -0.79 dan nilai koefisien regresi (b) dukungan sebaya -1.07 (LoC b $=-0.31$; CI $95 \%=-0.674 \mathrm{~s} / \mathrm{d}-0.42 ; \mathrm{p}=0.001 ;$ dukungan sebaya $\mathrm{b}=-0.89 ; \mathrm{CI} 95 \%=-1.26 \mathrm{~s} / \mathrm{d}-0.53, \mathrm{p}=0.001)$. Ada pengaruh locus of control dan dukungan sebaya terhadap resiko depresi pada ODHA.
\end{abstract}

Kata-kata kunci: Dukungan Sebaya, Locus of Control, Resiko Depresi

\begin{abstract}
HIV incidence tends to increase with a high mortality rate, the epidemic has now hit all countries as well as all levels of the population, social problems will further complicate the psychic condition of ODHA in stress and depression. The purpose of this study was to analyze the influence of locus of control and peer support on the risk of depression in KDS Friendship plus Kediri City. This type of research is observational analytics with a cross sectional approach. This research was conducted on 23 - 24 April 2020. Sampling was done with simple random sampling techniques as many as 45 research subjects. Data collection techniques using questionnaires, analysis using multiple linear regressions. Effect of locus of control $p=0.001$ (29.8\%). Effect of peer support $p=0.001$ (52\%). The influence of locus of control and peer support $(p=0.001<0.005), 54 \%$ risk of depression in ODHA is influenced by locus of control and peer support factors, regression coefficient value $(b)$ locus of control -0.79 and regression coefficient value (b) peer support -1.07 ( $\mathrm{LoC} b=-0.31 ; C I$ 95\% $=-0.674$ to $-0.42 ; p=0.001$; peer support $b=-0.89 ; C I 95 \%=-1.26$ to $-0.53, p=0.001)$. There is a locus of control and peer support influence on the risk of depression in ODHA.
\end{abstract}

Keywords: Peer Support, Locus of Control, Depression Risk 
Jurnal Kesehatan Hesti Wira Sakti vol 9 No 12021

ISSN 2302-4283 (print)

ISSN 2580-9571 (online)

Online di https://jurnal.poltekkes-soepraoen.ac.id

DOI: $10.47794 /$

\section{PENDAHULUAN}

Virus HIV merupakan penyebab penyakit yang sangat mematikan sepanjang sejarah peradaban manusia (Selik et al., 2014). World Health Organization (WHO), menyatakan HIV sebagai wabah paling mematikan dan merupakan penyakit infeksi yang menjadi persoalan kesehatan masyarakat global dan tersebar hampir di seluruh negara di dunia, termasuk Indonesia. Masalah tersebut cenderung semakin meningkat dari tahun ke tahun dengan angka kematian yang tinggi (Yarchoan \& Uldrick, 2018).

Peningkatan angka kematian akibat epidemi HIV saat ini telah melanda seluruh negara dan pada semua lapisan penduduk. Data terbaru The World Bank, diperkirakan pada tahun 2013 terdapat 35 juta orang yang hidup dengan HIV; 2,1 juta orang telah terinfeksi HIV tahun itu, dan 1,5 juta meninggal karena penyakit terkait HIV (World Health Organization, 2016). Case Fatality Rate (CFR) atau angka kematian menurun dari 3,79\% pada tahun 2012 menjadi 0,46\% pada bulan September tahun 2013 (Ditjen PP \& PL Kemenkes RI, 2014). Sedangkan menurut Dinkes Kabupaten Kediri pada tahun 2019 di Kediri tercatat 
populasi berisiko HIV, akan lebih memperberat kondisi psikis mereka ketika mereka menerima vonis (Reini Astuti, Iyus Yosep, 2015). Kecemasan dan depresi menjadi salah satu penyebab terjadinya bunuh diri dan berdampak pada peningkatan angka bunuh diri (Katz et al., 2013). Diperkirakan 5\% sampai $15 \%$ dari orang-orang yang terkena depresi melakukan bunuh diri setiap tahunnya (Sierra et al., 2005). Depresi yang tidak tertanggulangi dengan baik dapat menurunkan sistim imunitas penderita HIV (Yarchoan \& Uldrick, 2018).

Pengendalian sebagai upaya penting dan merupakan program jangka panjang yang dilaksanakan secara terkoordinir dengan melibatkan berbagai pihak (Rueda et al., 2016). Sektor komunitas merupakan faktor penentu dalam mempercepat pencapaian 3 zeroes - zero infection baru, zero kematian terkait AIDS dan zero stigma dan diskriminasi. Penguatan sektor komunitas, yang terdiri dari Strategic Investment Framework (SIF), Community System Strengthening (CSS), Expanded Readiness Assessment (ERA), Organizational Performance (OP) dan Technical Capacity (TC), Institutional Development Framework (IDF), Discussion-
Oriented Organizational Self Assessment (DOSA), Organizational Capacity Assessment Tool (OCAT). Pemberian dukungan melalui jaringan sosial, dukungan keluarga maupun dukungan sebaya harus digalakkan (Idele et al., 2014).

Pemerintah juga telah mendorong untuk meningkatkan tanggung jawab keluarga dan masyarakat terhadap orang dengan HIV dan AIDS (ODHA) (Pusat Kebijakan dan Manajemen Kesehatan Fakultas Kedokteran UGM, 2013). Berdasarkan uraian di atas, maka peneliti terdorong untuk melakukan penelitian dengan merumuskan dalam judul "Pengaruh Locus of Control dan Dukungan Sebaya Terhadap Resiko Depresi pada Orang dengan HIV/AIDS di KDS Friendship Plus Kota Kediri”.

\section{METODE PENELITIAN}

Jenis penelitian yang digunakan adalah penelitian analitik observasional dengan pendekatan cross sectonal (Murti, 2013). Variabel bebas (LoC dan dukungan sebaya) dan variabel terikat (resiko depresi pada ODHA) diukur dengan memperhatikan jumlah kasus terlebih dahulu.

Penelitian dilakukan di KDS Friendship plus Kota Kediri 
Jurnal Kesehatan Hesti Wira Sakti vol 9 No 12021

ISSN 2302-4283 (print)

ISSN 2580-9571 (online)

Online di https://jurnal.poltekkes-soepraoen.ac.id

DOI: $10.47794 /$

dilaksanakan pada April 2020. Sampel

dalam penelitian ini adalah sebagian orang dengan HIV/AIDS (ODHA) di KDS Friendship Plus Kota Kediri. Ukuran sampel diperkirakan menurut desain analisis data yang akan dilakukan, yaitu analisis multivariat yang melibatkan dua variabel independen. Dalam model analisis multivariat dibutuhkan 15-20 subjek penelitian per sebuah variabel independen. Jadi dalam penelitian ini minimal dibutuhkan $3 \mathrm{x}$ $(15$ hingga 20 subjek $)=45$ hingga 60 subjek penelitian (Murti, 2013).

Pengambilan sampel dilakukan dengan teknik pencuplikan random sederhana (simple random sampling). Kriteria inklusi meliputi : (a) ODHA, (b)

Bersedia menjadi responden dengan menandatangani informed consent, (c) Sudah masuk kelompok KDS Friendship Plus Kota Kediri, (d) Mengikuti pertemuan yang akan diselenggarakan oleh panitia KDS Friendship Plus Kota Kediri pada bulan April 2020.

Pengolahan data secara univariat, bivariat untuk mengetahui hubungan antar variabel menggunakan pearson product moment dan analisis multivariat dengan analisis regresi linier berganda dengan variabel LoC, Dukungan sebaya dan resiko depresi.

\section{HASIL PENELITIAN}

Karakteristik subjek penelitian berdasarkan usia, pendidikan, pekerjaan, faktor risiko, status marital, dan jenis kelamin.

Tabel 1 Hasil Analisis Univariat Pengaruh Locus of Control dan Dukungan Sebaya Terhadap Resiko Depresi Pada Orang Dengan HIV di KDS Friendship Plus Kota Kediri

\begin{tabular}{ccccc}
\hline No & Variabel & Kategori & n & $\%$ \\
\hline 1 & Umur & $<20$ tahun & 8 & 17,7 \\
& & $20-35$ tahun & 12 & 26,7 \\
& & $>35$ tahun & 25 & 55,6 \\
2 & \multirow{2}{*}{ Pendidikan } & SD / SMP & 27 & 60,0 \\
& & SMA & 12 & 26,7 \\
& & PT & 6 & 13,3 \\
3 & \multirow{2}{*}{ Pekerjaan } & WPS & 14 & 31,1 \\
& & Tidak Bekerja & 13 & 28,8 \\
& & Swasta & 10 & 22,4 \\
& & Dagang & 8 & 17,7 \\
4 & \multirow{2}{*}{ Faktor resiko } & Beresiko & 28 & 62,2 \\
& & Tidak Beresiko & 17 & 37,8 \\
5 & Status & Janda & 17 & 37,8 \\
\hline
\end{tabular}




\begin{tabular}{|c|c|c|c|c|}
\hline \multirow{4}{*}{6} & \multirow{4}{*}{ Jenis kelamin } & Nikah & 15 & 33,4 \\
\hline & & Tidak Menikah & 13 & 28,8 \\
\hline & & Perempuan & 36 & 80,0 \\
\hline & & Laki-laki & 9 & 20,0 \\
\hline
\end{tabular}

Didapatkan sebagian besar dari responden berusia 35 tahun yaitu sebanyak 25 responden (55.6\%), hampir seluruhnya responden berpendidikan rendah yaitu SD dan SMP sebanyak 27 responden $(60.0 \%)$, hampir setengahnya responden memiliki pekerjaan sebagai WPS yaitu sebanyak 14 responden (31.1\%), sebagian besar responden memiliki faktor risiko terkena HIV yaitu WPS sebanyak 14 responden $(31,1 \%)$, hampir setengah responden berstatus marital janda yaitu sebanyak 17 responden $(37.8 \%)$, dan hampir seluruhnya responden berjenis kelamin perempuan yaitu sebanyak 36 responden (80\%) dari total 45 responden.

Tabel 2 Hasil Analisis Regresi linier pengaruh Locus of Control dan

Dukungan Sebaya terhadap resiko Risiko Depresi pada ODHA

\begin{tabular}{lccc}
\hline Variabel Independen & Koefisien regresi b & $\mathrm{t}$ & $\mathrm{p}$ \\
\hline Konstanta & 122.53 & 10.16 & 0.001 \\
Locus of Control & -0.31 & -1.78 & 0.001 \\
Dukungan Sebaya & -0.89 & -4.71 & 0.001 \\
n observasi $=45$ & & & \\
Ajusted $\mathrm{R}^{2}=54 \%$ & & & \\
$\mathrm{p}<0.05$ & & & \\
\hline
\end{tabular}

Sumber: Data Primer, 2020

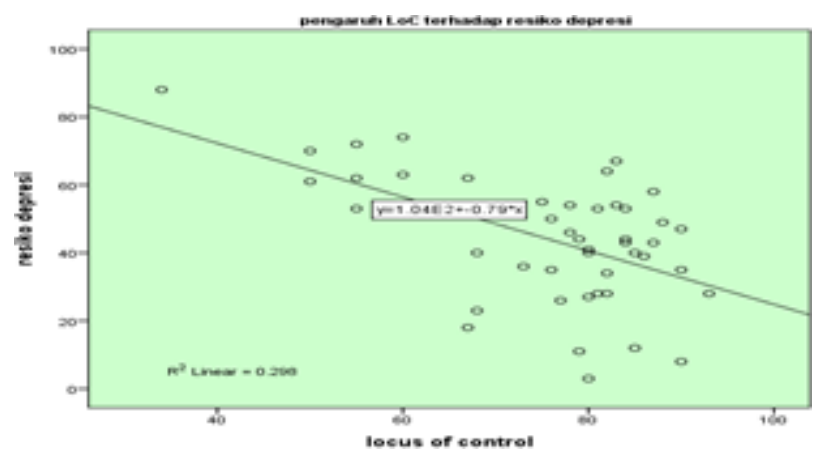

Gambar 1 Diagram Scatter Plot Pengaruh LoC Terhadap Resiko Depresi pada ODHA di KDS Friendship Plus Kota Kediri Jawa Timur 
Online di https://jurnal.poltekkes-soepraoen.ac.id

DOI: $10.47794 /$

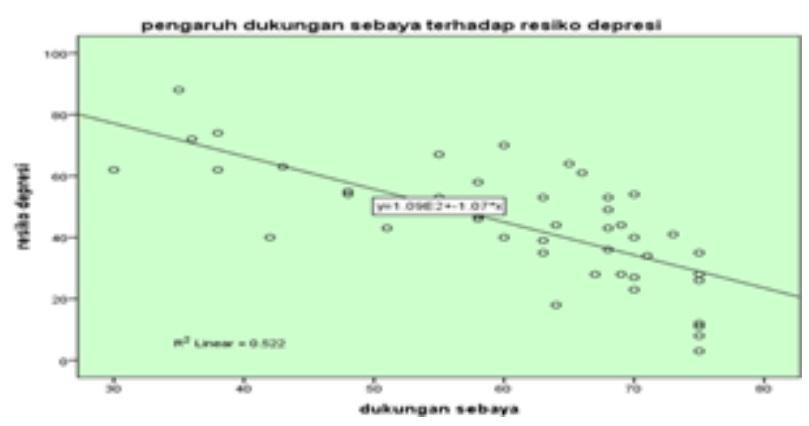

Gambar 2 Diagram Scater Pengaruh Dukungan Sebaya Terhadap Resiko Depresi pada

ODHA di KDS Friendship Plus Kota Kediri Jawa Timur

Pada pengujian normalitas menggunakan metode kolmogorovsmirnov hasil untuk semua variabel adalah normal, dan hasil pengujian linieritas untuk semua variabel adalah linier. Pengaruh secara multivariat menjelaskan tentang pengaruh lebih dari satu variabel independen locus of control, dukungan sebaya terhadap variable dependent risiko depresi pada ODHA.

\section{PEMBAHASAN}

Pengaruh LoC terhadap risiko depresi pada ODHA yaitu dengan semakin tinggi skor LoC maka hasil resiko depresi semakin rendah $(\mathrm{p}=$ 0.001). Koefisien determinasi $\mathrm{r} \quad \mathrm{Sq}$ Linier $\left(\mathrm{R}^{2}\right) \quad 0.29$ artinya $29.8 \%$ resiko depresi pada ODHA dipengaruhi oleh dukungan sebaya sedangkan sisanya $70.2 \%$ karena faktor lain yang tidak dapat dijelaskan dalam persamaan regresi tersebut. Koefisien regresi (b) adalah -0.79 (bernilai negatif) artinya tanpa ada penambahan skor LoC maka memberikan kemungkinan penurunan resiko depresi sebesar 0.79 kali atau dalam persamaan $\mathrm{y}=1.04 \mathrm{E} 2+-0.79 * \mathrm{x}$. Sedangkan tabel 5.7 analisis multivariat nilai $\mathrm{p}=0.001$, hal ini berarti ada pengaruh yang signifikan antara LoC terhadap resiko depresi pada ODHA.

LoC adalah suatu hal yang dipastikan memberikan kontribusi terhadap kualitas seseorang, yaitu respon awal sebagai dasar dari respon yang akan dilakukan selanjutnya (Kandwal et al., 2009). LoC adalah sikap seseorang dalam mengartikan sebab dari suatu peristiwa. LoC merupakan salah satu variabel kepribadian yang didefinisikan sebagai keyakinan individu terhadap mampu tidaknya 
mengontrol nasib (destiny) sendiri (Milz et al., 2016). LoC meliputi internal dan eksternal LoC. Seseorang dengan internal LoC adalah mereka yang merasa bertanggung jawab atas kejadian tertentu. Hasilnya adalah dampak langsung dari tindakannya. Sedangkan orang dengan external LoC adalah mereka yang sering menyalahkan atas keberuntungan, petaka, nasib, keadaan dirinya atau kekuatan lain di luar kekuasaannya (Campbell et al., 2008). Individu yang memiliki keyakinan bahwa nasib dalam kehidupannya berada di bawah kontrol dirinya dikatakan sebagai individu yang memiliki internal LoC (Ruffin et al., 2012). Sementara itu, individu yang memiliki keyakinan bahwa lingkungan mempunyai kontrol terhadap nasib yang terjadi dalam kehidupannya dikatakan bahwa individu itu sebagai individu yang memiliki external LoC (Mashamba et al., 2011).

LoC internal yang baik pada anak akan mendorong mereka untuk terbuka kepada orang lain tentang status mereka dan keluarganya dikaitkan tekanan, stigma dan depresi (Sharp \& Hahn, 2010). LoC yang internal menurunkan depresi dan meningkatkan kualitas kesehatan terutama mental di pedesaan
Uganda (Uganda AIDS Commission, 2017). LoC eksternal pada masa remaja adalah salah satu faktor mediasi hubungan antara kesulitan awal dan depresi pada 18 tahun. intervensi kognitif yang berusaha untuk mengubah keyakinan kontrol maladaptif pada masa remaja mungkin efektif dalam mengurangi risiko depresi setelah awal kesulitan hiduh (Culpin et al. 2013).

Hasil analisis menunjukkan terdapat pengaruh LoC terhadap risiko depresi pada ODHA (Charjer CJ, 2011). Ketika seseorang tertimpa suatu bencana (termasuk saat ini sedang menderita HIV/AIDS), maka semua itu dianggap mengarah pada keyakinan bahwa ada konsekuensi hasil atas perbuatan diri sendiri. Individu percaya bahwa hasil baik yang diperoleh dan kegagalan yang diperoleh merupakan hasil dari perilakunya sendiri, sehingga ia percaya bahwa yang mengontrol berhasil tidaknya suatu tujuan adalah dirinya sendiri (Bunnell et al., 2008). Bisa jadi yang berpengaruh terhadap depresi ini berasal dari pemikiran bahwa kesakitannya ini sebagai kesalahannya sendiri (LOC internal), atau bisa juga dia menyalahkan lingkungan (bisa teman, pacar, istri, suami atau siapapun) di luar dirinya 
(LOC eksternal). Apapun pola pemikiran yang berkembang, pada umumnya mereka mengetahui dan menyadari bahwa tiada harapan kesembuhan dari penyakitnya. Tentu saja kondisi demikian akan mempengaruhi kondisi psikologisnya sehingga semakin memicu timbulnya depresi (Mushi, 2017).

Pengaruh dukungan sebaya terhadap risiko depresi pada ODHA yaitu dengan semakin tinggi skor dukungan sebaya maka hasil resiko depresi semakin rendah $(\mathrm{p}=$ 0.001 $)$ Koefisien determinasi r Sq Linier $\left(\mathrm{R}^{2}\right) 0.52$ artinya $52 \%$ resiko depresi pada ODHA dipengaruhi oleh dukungan sebaya sedangkan sisanya $48 \%$ karena faktor lain yang tidak dapat dijelaskan dalam persamaan regresi tersebut. Koefisien regresi (b) adalah -1.07 (bernilai negatif) artinya tanpa ada penambahan skor dukungan sebaya maka memberikan kemungkinan penurunan resiko depresi sebesar 1.07 kali atau dalam persamaan $\mathrm{y}=1.09 \mathrm{E} 2+-1.07 * \mathrm{x}$. Sedangkan tabel

5.7 analisis multivariat nilai $\mathrm{p}=0.001$, hal ini berarti ada pengaruh yang signifikan antara dukungan sebaya terhadap resiko depresi pada ODHA.
KDS adalah suatu kelompok dua atau lebih orang yang terinfeksi atau terpengaruh langsung oleh HIV berkumpul dan saling mendukung. Anggota KDS adalah orang dengan HIV/AIDS (ODHA) dan orang yang hidup dengan ODHA (OHIDHA), atau gabungan dari ODHA dan OHIDHA. Awalnya berupa gabungan ODHA dengan latar belakang berbeda dan adanya kebutuhan untuk membuat kelompok yang lebih spesifik, seperti kelompok khusus ODHA saja, atau dengan latar belakang tertentu (Waria, IDU, Perempuan, dan lain-lain), atau gabungan ODHA dan OHIDHA. KP berperan mengoordinasi, mengakomodasi aspirasi dan kebutuhan dari KDS-KDS yang dilayani, menumbuhkan kesadaran kritis, mengayomi, dan membimbing KDSKDS dengan menjunjung nilai kesetaraan serta sebagai pelaku advokasi dengan melibatkan KDS dalam proses. Fungsi KP untuk mencegah atau mengantisipasi terjadinya konflik antar KDS, memberikan dukungan kepada KDS, memberikan kesempatan kepada KDS untuk dapat tumbuh bersama secara sehat, memastikan pemakaian dana yang 
diberikan KP untuk digunakan semestinya, dan menjadi wadah dan saluran informasi untuk semua KDS yang dilayani (Yayasan Spiritia, 2011).

Kelompok Dukungan Sebaya merupakan faktor eksternal yang memengaruhi kepatuhan terapi ARV. KDS mempunyai tugas memberikan motivasi dan mendampingi ODHA. Tugas buddy atau KDS sebagai pendamping penderita ODHA adalah memberitahukan secara mendalam mengenai penyakit HIV/AIDS (Yayasan Spiritia, 2011). Dukungan sebaya meningkatkan fungsi psikososial jauh lebih baik mengenai ketidakpastian sakit, depresi dan kepuasan dengan dukungan sosial pada kelompok kontrol yang baru didiagnosis dengan HIV (Brashers DE et al.2013)

Hasil analisis menunjukkan terdapat pengaruh signifikan, dukungan sebaya pada ODHA. Hal ini disebabkan karena LSM ini memang satu-satunya saluran untuk dapat menyalurkan isi hati, curahan emosional dan beban psikologis yang selama ini tidak dapat dilaksanakan atau diungkapkan oleh penderita kepada siapapun termasuk anggota keluarganya. Di Kota Kediri dan sekitarnya kondisi penderita HIV/AIDS menyadari betul bahwa kelompok ini memiliki nasib yang sama, sama-sama menghadapi resiko kesakitan dan kematian yang sama, dan sama-sama tahu kalao samasama menderita HIV/AIDS, maka jika kelompok ini tidak saling memberikan dukungan, yang terjadi adalah penderita merasa tidak ada tempat lain yang dapat digunakan untuk meluapkan emosionalnya, tidak ada tempat untuk meminta dukungan dari penyakitnya, tidak ada lagi yang diharapkan mampu memberikan bantuan moril dan berbagai perasaan psikologis lainnya.

Sebaliknya jika kelompok ini mampu menjalankan fungsinya dengan baik maka penderita merasa masih ada orang yang peduli dengan dirinya, masih ada harapan sebagai tempat mencurahkan isi hati dan perasaan, masih ada harapan yang akan memberikan bantuan dan perhatian. Manusia memiliki sisi psikologis dan fisiologis. Kebutuhan psikologis ini yang sangat utama bagi penderita HIV/AIDS. Jika dukungan sebaya tidak berfungsi dengan baik maka penderita merasa sudah tidak ada harapan lagi, maka akan semakin menambah beban psikologisnya sehingga memicu timbulnya perasaan depresi. 
Jurnal Kesehatan Hesti Wira Sakti vol 9 No 12021

ISSN 2302-4283 (print)

ISSN 2580-9571 (online)

Online di https://jurnal.poltekkes-soepraoen.ac.id

DOI: $10.47794 /$

Analisis multivariat diketahui Adjusted $\mathrm{R}^{2}=54 \%$ ini berarti secara keseluruhan variabel LoC dan dukungan sebaya memberi pengaruh terhdap resiko depresi sebesar 54\% koefisien regresi (b) LoC dan dukungan sebaya adalah 122.32 (bernilai positif) artinya tanpa ada penambahan skor LoC dan dukungan sebaya maka memberikan kemungkinan penurunan resiko depresi sebesar 122.32 kali. Nilai $\mathrm{p}=0.001$, hal ini berarti ada pengaruh yang signifikan antara LoC dan dukungan sebaya terhadap resiko depresi pada ODHA (LoC $b=-0.31$; CI $95 \%=-0.674 \mathrm{~s} / \mathrm{d}-0.42 ; \mathrm{p}=0.001 ;$ dukungan sebaya $b=-0.89$; CI $95 \%=-$ $1.26 \mathrm{~s} / \mathrm{d}-0.53, \mathrm{p}=0.001)$.

Penelitian mengemukakan gambaran konsep diri pada penderitaHIV/AIDS secara keseluruhan berada pada kategori kurang atau bahkan sangat kurang (Situmeang et al., 2017). Salah satu penyebab kurangnya konsep diri ini adalah sikap negatif dari masyarakat. Penderita HIV umumnya telah mencoba untuk memperbaiki diri dengan bersikap baik di lingkungan masyarakat, namun sikap dan pandangan negatif dari masyarakat seakan menyudutkan mereka sehingga sangat mempengaruhi konsep diri mereka (Anggina et al., 2019).

Keefektivitasan dukungan sebaya diyakini berasal dari berbagai proses psikososial seperti yang dijelaskan, yaitu dukungan sosial, pengetahuan pengalaman, teori pembelajaran sosial, teori perbandingan sosial, dan prinsip menolong sebagai bagian dari terapi (Yayasan Spiritia, 2011). Terdapat pengaruh yang terbalik (negatif) antara locus of control dan dukungan sebaya terhadap risiko depresi.

\section{KESIMPULAN}

LoC dan dukungan sebaya sangat dibutuhkan dalam menurunkan tingkat depresi ODHA, sehingga pengobatan dan kehidupan sosial akan berjalan sesuai semestinya tanpa terbebani penyakitnya. Peran dukungan sebaya adalah meningkatkan pengendalian diri mencapai mutu hidup yang lebih baik bagi ODHA dan OHIDHA.

Peran keluarga, masyarakat dan tenaga kesehatan harus dilibatkan untuk selalu mendorong mengikuti petunjuk tenaga kesehatan tentang perawatan penyakitnya sehingga kualitas hidup ODHA terjaga. 


\section{DAFTAR PUSTAKA}

Anggina, Y., Lestari, Y., \& Zairil, Z. (2019). Analisis Faktor yang Mempengaruhi Penanggulangan HIV/AIDS di Wilayah Kerja Dinas Kesehatan Kabupaten Padang Pariaman Tahun 2018. Jurnal Kesehatan Andalas. https://doi.org/10.25077/jka.v8.i2.p 385-393.2019

Awofala, A. A., \& Ogundele, O. E. (2018). HIV epidemiology in Nigeria. In Saudi Journal of Biological Sciences. https://doi.org/10.1016/j.sjbs.2016. 03.006

Brashers DE1, Basinger ED1, Rintamaki LS2, Caughlin JP1, Para M3. 2013. Taking control: the efficacy and and durability of a peer-led uncertainty management intervention for people recently diagnosed with HIV. Health commun. 2013 apr 27:1-11, doi:10.1060/10410236.2015.1089 469.

(http://www.ncbi.nlm.nih.gov/pub med/27119222)

Bunnell, R., Opio, A., Musinguzi, J., Kirungi, W., Ekwaru, P., Mishra, V., Hladik, W., Kafuko, J., Madraa, E., \& Mermin, J. (2008). HIV transmission risk behavior among HIV-infected adults in Uganda:

Results of a nationally representative survey. AIDS. https://doi.org/10.1097/QAD.0b01 3e3282f56b53

Campbell, J. C., Baty, M. L., Ghandour, R. M., Stockman, J. K., Francisco, L., \& Wagman, J. (2008). The intersection of intimate partner violence against women and HIV/AIDS: a review. In
International journal of injury control and safety promotion. https://doi.org/10.1080/174573008 02423224

Carter CJ. 2011. Extensive viral mimicry of 22 AIDS-related autoantigens by HIV-1 proteins and pathway analysis of 561 viral/human homologues suggest an initial treatable autoimmune component of AIDS. Journal Federation of European Microbiological Societies Published by Blackwell Publishing Ltd. All rights reserved. FEMS Immunol Med Microbiol 63 (2011) 254-268. published online $12 \quad$ August 2011. (http://www.ncbi.nlm.nih.gov/pub med/ 22077229).

Culpin I1, Stapinski L2, Miles ÖB3, Araya R4, Joinson C5. 2013. Exposure to socioeconomic adversity in early life and risk of depression at 18 years: The mediating role of locus of control. $\mathrm{J}$ affect disord. 2015 sep1.18326978. doi:10,1016j.jad.2013.05.030 (http://www.ncbi.nlm.nih.gov/pub $\mathrm{med} / 26047$ 304)

Ditjen PP \& PL Kemenkes RI. (2014). Statistik Kasus HIV/AIDS di Indonesia Dilapor s/d September 2014. Kemenkes RI.

Idele, P., Gillespie, A., Porth, T., Suzuki, C., Mahy, M., Kasedde, S., \& Luo, C. (2014). Epidemiology of HIV and AIDS Among Adolescents. JAIDS Journal of Acquired Immune Deficiency Syndromes. https://doi.org/10.1097/qai.000000 0000000176

Kandwal, R., Garg, P. K., \& Garg, R. D. (2009). Health GIS and HIV/AIDS studies: Perspective and 
retrospective. In Journal of Biomedical Informatics. https://doi.org/10.1016/j.jbi.2009.0 4.008

Katz, I. T., Ryu, A. E., Onuegbu, A. G., Psaros, C., Weiser, S. D., Bangsberg, D. R., \& Tsai, A. C. (2013). Impact of HIV-related stigma on treatment adherence: systematic review and metasynthesis. In Journal of the International AIDS Society. https://doi.org/10.7448/ias.16.3.18 640

Mashamba, T., Peltzer, K., Maluleke, T. X., \& Sodi, T. (2011). A controlled study of an HIV/AIDS/STI/TB intervention with faith healers in Vhembe District, South Africa. African Journal of Traditional, Complementary and Alternative Medicines.

https://doi.org/10.4314/ajtcam.v8i5 S.16

Milz, R. U., Husstedt, I. W., Reichelt, D., \& Evers, S. (2016). Control beliefs and health locus of control in Ugandan, German and migrated sub-Saharan African HIV infected individuals. Journal of Psychosomatic Research. https://doi.org/10.1016/j.jpsychore s.2016.02.005

Murti, B. (2013). Desain dan Ukuran Sampel Untuk Penelitian Kuantitatif dan Kualitatif di Bidang Kesehatan. UGM Press.

Mushi, K. E. (2017). HIV and AIDS in East and Southern Africa regional overview. In Avert.
Olagunju AT, adeyemi JD, Ogbolu RE, Campbell EA. 2012. A Study on Epidemiological Profile of Anxiety Disorders among people living with HIV/AIDS in a subSaharan Africa HIV clinic. Springer Journal 2012. http://www.ncbi.nlm.nih.gov/pu bmed/22772942.

Reini Astuti, Iyus Yosep, R. D. S. (2015). Effect of Intervention Spiritual Emotional Freedom Technique Toward Decrease The Level Of Depretion Houswife With HIV In Bandung. Universitas Padjajaran.

Rueda, S., Mitra, S., Chen, S., Gogolishvili, D., Globerman, J., Chambers, L., Wilson, M., Logie, C. H., Shi, Q., Morassaei, S., \& Rourke, S. B. (2016). Examining the associations between HIVrelated stigma and health outcomes in people living with HIV/AIDS: a series of meta-analyses. BMJ Open. https://doi.org/10.1136/bmjopen2016-011453

Ruffin, R., Ironson, G., Fletcher, M. A., Balbin, E., \& Schneiderman, N. (2012). Health locus of control beliefs and healthy survival with AIDS. International Journal of Behavioral Medicine. https://doi.org/10.1007/s12529011-9185-2

Selik, R. M., Mokotoff, E. D., Branson, B., Michele Owen, S., Whitmore, S., \& Irene Hall, H. (2014). Revised surveillance case definition for HIV infection - United States, 2014. MMWR Recommendations and Reports. 
Sharp, P. M., \& Hahn, B. H. (2010). The evolution of HIV-1 and the origin of AIDS. In Philosophical Transactions of the Royal Society B: Biological Sciences. https://doi.org/10.1098/rstb.2010.0 031

Sierra, S., Kupfer, B., \& Kaiser, R. (2005). Basics of the virology of HIV-1 and its replication. In Journal of Clinical Virology. https://doi.org/10.1016/j.jcv.2005.0 9.004

Situmeang, B., Syarif, S., \& Mahkota, R. (2017). Hubungan Pengetahuan HIV/AIDS dengan Stigma terhadap Orang dengan HIV/AIDS di Kalangan Remaja 15-19 Tahun di Indonesia (Analisis Data SDKI Tahun 2012). Jurnal Epidemiologi Kesehatan Indonesia. https://doi.org/10.7454/epidkes.v1i 2.1803

Tarkang, E. E., \& Zotor, F. B. (2015). Application of the Health Belief Model (HBM) in HIV Prevention: A Literature Review. In Science Publishing Group.

Uganda AIDS Commission. (2017). Uganda Population Based HIV Impact Assessment. Uac.

World Health Organization. (2016). Global health sector strategy on viral hepatitis 2016-2021. Global
Hepatitis Programme Department of HIV/AIDS.

Yarchoan, R., \& Uldrick, T. S. (2018). HIV-Associated Cancers and Related Diseases. New England Journal of Medicine. https://doi.org/10.1056/nejmra161 5896

Yayasan Spiritia. 2014. Depresi. berdasarkan FS $558 \mathrm{~T}$ he AIDS InfoNet 23 Juli 2014. http://spiritia.or.id/li/baca li.php?lino=558,

Yayasan Spiritia. 2011. Peran Dukungan Sebaya terhadap Peningkaan Mutu Hidup ODHA di Indonesia Tahun 2011. Komisi Penanggulangan AIDS Nasional, FordFoundation, AusAI

Yudiati, E. A., \& Rahayu, E. (2017). Hubungan Antara Coping Stres Dengan Kecemasan Pada OrangOrang Pengidap HIV/AIDS Yang Menjalani Tes Darah Dan Vct (Voluntary Counseling Testing). PSIKODIMENSIA.

https://doi.org/10.24167/psiko.v15i 2.995

Initiation of Antiretroviral Therapy in Early Asymptomatic HIV Infection. (2015). New England Journal of Medicine. https://doi.org/10.1056/nejmoa150 6816 